lift), modern plants consume about 0.8 h.p. hour per ton. This represents a very low efficiency. In a vertical pipe a fluid ascends more quickly than a suspended material, their relative velocity being the 'terminal velocity' in this case.

\section{A Zinc 'Famine'}

AcCordING to the Electrical Contractor and Retailer an idea was current a short time ago that a shortage of zinc was responsible for the recent famine in torchbatteries. This is not the case as there was plenty of zine in Great Britain and the torch-battery famine was due entirely to the overwhelming Government and public demand for these accessories-and quite naturally so. When a large number of people suddenly resolve to carry flash-lamps, something like a temporary famine is unavoidable. During the life of an ordinary dry battery possibly five per cent of the zinc is consumed and so about 95 per cent of the zinc used for this service is thrown away. It looks as if we were surrounded by an appalling waste in various directions. Notice, for example, the packing of tobacco and cigarettes for domestic use in 'tins' and then visualize the waste of iron and tin thereby involved. Many of these tins are also provided with substantial rubber seals, all of which are used once and then thrown away. It would be of interest if somebody considered whether this waste is serious or not, and if it is, then investigate how the saving could be effected.

\section{Training Physicists}

DURING the last six years there has been much discussion in the United States as to the most suitable training for physicists who are required in industry, and the conclusions come to have been summarized in these columns. In general, the training then available was considered to provide a superficial acquaintance with the latest developments of quantum theory and of atomic disintegration rather than a fundamental knowledge of the older physics. Criticisms of the same type were made in the May issue of Metals and Alloys this year and were quoted in the July issue of the Journal of Scientific Instruments.

In the November issue of the Journal, two physicists in the research department of a cable works in Great Britain point out that the criticism applies equally well to the training the universities of Great Britain provide, and that in consequence industrialists are reluctant to employ physicists. They think that the position would be improved if the universities provided some training in applied physics and supplemented it by visits to works and by practical experience in works during vacations.

\section{Fused All-Glass Cells}

Messrs. Tintometer Ltw., of Salisbury, announce the manufacture of a range of fused all-glass cells suitable for holding liquids for colorimetry, photometry, polarimetry and other purposes. The construction of the standard type consists of a body of a single bend of glass with faces of clear glass sintered to it. This avoids the use of the usual cements, which often break down under the attack of alkalis and other solvents. It is claimed that the accuracy of the thickness is within $\pm 4 \times 10^{-3} \mathrm{in}$. for cells of one inch or less; moreover, examination shows that distortion of the faces in the sintering process has been very largely avoided. Beside the standard types, hollow cubes, prisms, rectangular cells, double light-filter cells, and 'blood' cells are also being manufactured. It appears that these products will form a useful addition to the range of such articles manufactured in Great Britain.

\section{Rhodes Scholars}

THE "Statement of the Rhodes Scholarships" for the academic year 1938-39 shows that 68 scholars began their English experience, while 188 were in residence. Among the subjects covered, natural science and medicine with 45 representatives, and jurisprudence and the Modern Greats school with 38 each are easily the most popular. Agriculture, forestry and music have solitary devotees. The record is good on the whole in academic distinctions, and includes several names well known in sport and athletics. The list of books published by men of the foundation is long. The Rhodes scholars include a dean of Christ Church and a regius professor of medicine. They come to England with previous academic training and at an age more advanced than that of the average undergraduate. The question whether this discrepancy is advisable has been the subject of considerable comment.

\section{Scientific Research in India}

THE progress of research in India can be followed by the help of the Indian Science Abstracts, which is an annotated bibliography arranged by subjects. Some of these bear closely on the economic development of the country, and their principal interest is local rather than general. Part 1 for the year 1937 covers mathematics, physics, geology and botany (National Institute of Sciences of India, September 1939). Mathematies has 86 papers, five of which deal with Indian geodesical problems, physics has 189 , only a dozen of which deal with local meteorological or geophysical subjects; geology has 316 and botany 286, dealing almost exclusively with Indian problems.

\section{Alchemical Manuscripts}

Volume 6 of Osiris, dedicated to Prof. Bidez, contains his portrait and a bibliography of his publications. The rest of the volume of 844 pages consists of a "Catalogue of Latin and Vernacular Alchemical Manuscripts in the United States and Canada" by W. J. Wilson, of the Library of Congress, Washington. After a brief but very interesting general introduction, the text consists of detailed and annotated analyses of 79 manuscripts, with 41 facsimile figures. The dates of the manuscripts range from the thirteenth to the nineteenth centuries. Many of them contain collections of recipes. There is a very full index (pages 690-844). The work is thorough and reaches a high standard of scholarship; 
it is a notable addition to the literature of a subject which has recently attracted a good deal of attention, namely, the history of alchemy.

\section{Early Works on Medicine and Science}

WF have received from Messrs. Goldschmidt and Co., Ltd., 45 Old Bond Street, W.1, their Catalogue No. 53 listing rare early works on medicine and science. Pride of place is occupied by a good and large copy in vellum of the first edition of William Harvey's "De Motu Cordis" (1628), and also a copy of the rare third edition of the same work. A complete set of Conrad Gesner's "Natural History" (1551), three of Kepler's important works, a work by Joseph Black on alkalis (1770) and William Withering's "An Account of the Foxglove" are also to be noted. A number of less rare though none the less important books and tracts by Erasmus Darwin, Euler, Faraday, Fayrer, Fraunhofer, Stephen Hales, Mendeléeff, Pasteur, Lister, Fox Talbot and many others are also listed.

\section{Medical and Scientific Lending Library}

PART 2 of the new edition of the "Catalogue of Lewis's Medical and Scientific Lending Library", revised to the end of 1937 , has now been issued (London: H. K. Lewis and Co., Ltd., 136 Gower Street, W.C.1. 16s. net; to subscribers, 8s.). It contains the classified index of the subject-matter of the books, with the names of their authors, upon medical and scientific subjects contained in Lewis's Library. An extensive subject is subdivided to facilitate reference; for example, chemistry has eleven, and agriculture thirteen, sub-headings. The date of publication is given, and a note is frequently added to indicate the scope of the work. It will be appreciated what a large number of works is listed when it is mentioned that the text occupies 156 pages, each with three columns and each column containing authors' names of some 30-45 works. The catalogue should therefore prove a very useful general guide to medical and scientific books.

\section{Big Sunspots}

A BIG group of sunspots, originating about January 1 and growing rapidly, crossed the sun's central meridian on January 5 and reached the west limb on January 12. Between January 2 and 4, the area increased tenfold and measured 1,300 millionths of the sun's hemisphere on the latter date. Still expanding on January 5, the spots were clearly seen with the naked eye through the morning mist. In structure, the group was a typical stream with leader and follower spots and subsidiary spots in between. This group is the largest since last September, and indicates that, although the maximum of the 11year cycle is past, the sun is still generally active.

\section{Royal Institution Discourses}

The following Friday Evening Discourses have been arranged by the Royal Institution to be delivered before Easter. The discourses begin at 5 o'clock: January 19, Sir Leonard Woolley, "The
Latest Excavations at Atchana in North Syria"; January 26, Sir Noel Ashbridge, "Long Distance Broadcasting"; February 9, Prof. L. C. Martin, "Ultra-Violet and Electron Microscopy"; February 16, Sir William Bragg, "Physics in War-time"; March 1, Lord Eustace Percy, "Peace-making after War : Past History and Future Problems" ; March 8, Sir William Bragg, "Experiments from the Researches of Sir James Dewar"; March 15, Sir Frederick Keeble, "Agriculture and National Well-being".

\section{Announcements}

THE Harrison Lectureship Medal of the Pharmaceutical Society will be awarded to Mr. A. D. Powell at a meeting on January 9 at 7.30, when Mr. Powell will deliver the Harrison Memorial Lecture entitled "Drug Standards : their Development and Application".

THE next monthly meeting of the British Institute of Radiology will be held in the Reid-Knox Hall on January 19, at 2 p.m., when the following lectures will be delivered: Silvanus Thompson Memorial Lecture entitled "The Irradiation of Liquids", by Prof. F. L. Hopwood ; Mackenzie Davidson Memorial Lecture entitled "Maternal Mortality and Radiology", by Dr. L. A. Rowden.

The Friends of the National Libraries decided at their annual meeting to continue their activities during the War. Acquisitions during the year included a number of early and rare books on science presented to the Science Library at South Kensington, a volume of drawings by the architect, Edward Blore, of country houses and other buildings, given to the Royal Institute of British Architects, and the purchase of a collection of papers belonging to the publishing business of Robert Cadell, Stoneham and Houlston.

The Paris Academy of Medicine has awarded the Jansen Prize to Prof. A. Bessemans, pro-rector of the University of Ghent, for his work on spirochætes.

THe Albert Brachet Prize of 12,000 francs is awarded every three years for the best work on embryology published during this period in English, French, Dutch, German or Italian. Further information can be obtained from the Secrétarie perpétuel de l'Académie Royale des Sciences, des Lettres et des Beaux Arts de Belgique, Palais des Académies, Brussels.

The Emergency Executive Committee of the International Congress of Mathematicians has decided definitely to postpone until some more favourable date the Congress which was to have been held in Cambridge in September 1940.

A Eurasian Youth Movement has been launched in Singapore with a scheme to uphold and improve the social, moral, physical and intellectual welfare of the Eurasian youth when they leave school. 